\title{
Soil effect on polyphenols content and antioxidant capacity of new hybrid variety of cocoa from Côte d'Ivoire
}

\author{
Kicho Denis YAPO ${ }^{1 *}$, Sébastien Koffi OUFFOUE ${ }^{1}$, Timothée Aboua OKPEKON ${ }^{1}$ and \\ Tanoh Hilaire KOUAKOU ${ }^{2}$ \\ ${ }^{1}$ UFR SSMT, Laboratoire de Chimie Organique Structurale, Université Félix Houphouët Boigny, \\ Côte d'Ivoire. \\ ${ }^{2}$ UFR des Sciences de la Nature, Laboratoire de Biologie et Amélioration des Productions Végétales, \\ Université Nangui Abrogoua, Côte d'Ivoire. \\ *Corresponding author; E-mail: yapokichodenis@yahoo.fr ; Tel: 00225497904 19; \\ 22 BP 582 Abidjan 22 Côte d'Ivoire
}

\begin{abstract}
Polyphenols have gained much interest recently due to their antioxidant capacity and possible benefits to human health. Cocoa (Theobroma cacao) is a rich source of polyphenols and has higher antioxidant activity than teas and red wines. Cocoa and its derived products contain different types of polyphenols and possess different levels of antioxidant. New hybrids called "cocoa mercedes" have been developed in Côte d'Ivoire for their precocity of production and an improved yield per hectare. The aim of this study is to assess the polyphenols content and antioxidant capacity of these new hybrids in correlation with their geographical sources. Crude extracts were obtained from freeze-dried beans and juice of cocoa in $80 \%$ methanol. Polyphenols were measured using the Folin-Ciocalteu's assay and antioxidant capacity by ORAC assay. Total extractable polyphenols were important with almonds followed by fermented juice and Abengourou gave the highest polyphenol content. Antioxidant capacity of almonds was found significantly higher than the other cocoa samples. Abengourou provided the best antioxidant capacity in comparison with other production areas of cocoa such as Adzope, Divo and Yamoussoukro. Effects of geographical sources could influence the polyphenol content and antioxidant capacity of cocoa.

() 2013 International Formulae Group. All rights reserved.
\end{abstract}

Keywords: Cocoa Mercedes, Folin-Ciocalteu, ORAC, human health, geographical sources

\section{INTRODUCTION}

Cocoa (Theobroma cacao L.) is known worldwide for its derived products such as chocolates. They are largely consumed worldwide due to their unique flavour and aroma that cannot be replaced by other plant products. Theobroma cacao is the only species cultivated in major producing countries for commercial purpose. During the last decade, numerous researches have been focused oncocoa polyphenols, especially the flavonoids, because of their antioxidant activity in human health (Martin et al., 2013; Engler et al., 2004; Abbe et al., 2008; Othmanet al., 2010). Antioxidants are known for their potential in promoting health and reducing the risk of cancer, hypertension and heart diseases (Martin et al., 2010; 
Kanadaswami et al., 2005; Valko et al., 2007; Cho et al., 2008). The main classes of polyphenolic compounds identified such as simple phenols, flavonoids, benzoquinones, phenolic acids, alcohols, stilbenes, tocopherols and tocotrienols have been reported to show good antioxidant activity (Hii et al., 2009; Jonfia-Essien et al., 2008). Polyphenols have become an intense focus of research interest because of their health beneficial effects (Othman et al., 2007; Martin et al., 2013), including anti-carcinogenic, antiatherogenic, anti-ulcer, anti-thrombotic, antiinflammatory, immune modulating, antimicrobial, vasodilatory and analgesic effects. Also, polyphenols played an increased protective role against cardiovascular disease, by regulating blood pressure, and aging diseases, including Alzheimer's disease particularly since they are the most abundant antioxidants in our diets. They have, a probable activity against HIV (Khanand Ather, 2007).

Generally, dietary sources of polyphenols are found in variety of fruits, plant beverages, vegetables, cereals, nuts, seeds and cocoa. Important researchers recently focused on cocoa polyphenols, particularly the flavonoids, and their functions as potent antioxidant in human health (Martin et al., 2010). Cocoa appears to be a very rich source of antioxidants and dietary flavonoids even compared to tea or red wine. Chocolate, a cocoa product, can also be a major source of dietary antioxidants, and these may have protective effects against cardiovascular disease (Keen et al. 2005; Fernández-Murgaet al., 2011).

Côte d'Ivoire is currently the leader in cocoa production and represents $35-40 \%$ of world cocoa bean production. However, the Forastero, Trinitario and Criollo which are the three main cocoa varieties (also called traditional cocoa) planted in Côte d'Ivoire have more than 40 years of age. This leads to a decline in cocoa production performance. To maintain its position as world leader in the production of cocoa, Côte d'Ivoire has undertaken, through the Centre National de Recherche Agronomique (CNRA), to renew his orchard with a new hybrid (www.cnra.ci). These new hybrid called "cocoa mercedes" has for main characteristics, the precocity of its production (24 months instead of 5 years for the traditional cocoa) and an improved yield ( 03 tons per hectare in year instead of 0.3 tons for traditional cocoa). It was massively introduced over the last 5 years in the fields by farmers because the seeds were free. However, very little is known about the level of essential nutrients such as antioxidants and phenolic compounds in this new cocoa hybrid.

The aim of the present study is to determine the total polyphenolic content (TPC) of this new cocoa hybrid of Côte d'Ivoire by using Folin-Ciocalteau method (FCM) and antioxidant capacity (Naczk and Shahidi, 2004). Measurements are done using a modified Oxygen Radical Absorbance Capacity (ORAC) assay (Davalos A. et al., 2004; Gillespie K. M. et al., 2007). The influence of the regional type of soil (geographical sources) on the quantity and antioxidant capacity of polyphenols is also investigated.

\section{MATERIALS AND METHODS \\ Materials}

The new hybrid variety of cocoa called "cocoa mercedes" has been developed by the Centre National de Recherche Agronomique de Côte d'Ivoire (www.cnra.ci). This hybrid was grown under tropical conditions at the experimental farm of the Centre National de Recherche Agronomique (CNRA) of Côte d'Ivoire at Abengourou (East) and Divo (south-west). Samples were done in these research stations of CNRA (Abengourou and Divo) and from orchard resulting new cocoa popularizing at Yamoussoukro (center) and Adzope (south-east). The harvested pods were broken to extract the beans. The fresh juice 
resulting from cocoa beans was collected and lyophilized. The beans were fermented for a period of four days. After fermentation, the beans were dried over the sun on mats made from palm leaves. The dry cocoa beans were sieved to remove dirt. Once they are dry, the cocoa bean integuments are separated from almonds. Thereafter, the integuments and almonds are processed separately in the powder state without roasting or any other methods of treatment. Each sample was stored in a cryopreservative condition at $-20{ }^{\circ} \mathrm{C}$ until used for the different analyzes.

\section{Methanolic extraction}

For each sample, freeze-dried cocoa sample (2 g) was extracted overnight with 10 ml methanol $80 \%$ at $4{ }^{\circ} \mathrm{C}$ in a blender. The obtained samples were centrifuged at 5000 rpm for $15 \mathrm{~min}$ and the supernatant was collected. The extract was used for the determination of both total polyphenolic content and antioxidant capacity.

\section{Determination of total polyphenolic content}

Total polyphenolic contents of all cocoa samples were determined using FolinCiocalteu reagent as described by Naczk and Shahidi (2004). Samples were inserted into different test tubes and mixed with $0.5 \mathrm{ml}$ Folin-Ciocalteu reagent (pre-dilute 10 times). After $3 \mathrm{~min}, 1.5 \mathrm{ml}$ of $17 \%$ sodium carbonate $\left(\mathrm{Na}_{2} \mathrm{CO}_{3}\right)$ was added to the mixture which was stored $45 \mathrm{~min}$ at room temperature, then the absorbance at $760 \mathrm{~nm}$ was recorded for each sample. Standard curve of gallic acid solution (10-100 $\mu \mathrm{g} / \mathrm{ml})$ was prepared using the similar procedure. The absorbance values obtained for the samples were finally extrapolated using the standard curves and expressed as milligram gallic acid equivalents (mg GAE) per gram freeze-dried extract (g FDE). All measures were performed in triplicate.

\section{Quantification of antioxidant capacity}

Evaluation of antioxidant capacity in methanolic cocoa extracts was performed using the modified Oxygen Radical Absorbance Capacity (ORAC) assay (Davalos A. et al., 2004; Gillespie K. M. et al., 2007). Solutions and extracts were prepared and further diluted appropriately using $75 \mathrm{mM}$ phosphate buffer $\mathrm{pH} 7.4$, which was also used as blank. $400 \mu \mathrm{L}$ of blank, then Trolox (6hydroxyl-2,5,7,8 - tetramethylchroman-2carboxyl acid), as a standard with a concentration range of $1.25-20 \mu \mathrm{M}$, and sample extract solutions were mixed with 180 $\mu 1$ of $1.17 \mathrm{mM}$ fluorescein (3',6'dihydroxyspiro [isobenzofuran-1[3H], 9' [9H]xanthen-3-one) stock solution in a silica container. The mixture was stirred with a micro bar, incubated and then adjusted to 37 ${ }^{\circ} \mathrm{C}$ during $10 \mathrm{~min}$. The reactions were initiated for 80 to $90 \mathrm{~min}$ by the addition of $90 \mu \mathrm{L}$ of 40 mM AAPH (2,2'-Azobis [2-amidinopropane] dihydrochloride) in each container. The fluorescence was monitored kinetically using a Fluorescence spectrophotometer (BMG Labtech Fluostar Optima) every 30 seconds with excitation wavelength of $485 \mathrm{~nm}$ followed by slit width $20 \mathrm{~nm}$, and emission wavelength of $530 \mathrm{~nm}$ followed by slit width $20 \mathrm{~nm}$. The reaction was stopped when the fluorescence intensity was below $2 \%$ of the initial fluorescence signal. ORAC values were then obtained by the extrapolation of net Area Under the Curve (AUC) of extracts, against the standard curve of net AUC of different Trolox concentrations, as follows:

$\mathrm{AUC}=(0.5+\mathrm{R} 2 / \mathrm{R} 1+\mathrm{R} 3 / \mathrm{R} 1+\mathrm{R} 4 / \mathrm{R} 1+\ldots+$ $\mathrm{Rn} / \mathrm{R} 1) \times \mathrm{RC}$

Net AUC = AUCextracts - AUCblank

$\mathrm{R} 1$ is the fluorescence intensity at the initiation of the reaction, $\mathrm{Rn}$ is the fluorescence signal measured at the last cycle, and $\mathrm{RC}$ is the period of reading cycle of fluorescence intensity measured in minutes. ORAC values were calculated as $\mu$ mol Trolox equivalent/gram $(\mu \mathrm{molTE} / \mathrm{g})$ of sample (Davalos et al., 2004; Gillespie et al., 2007). All experimental processes were performed in triplicate. 


\section{Statistical analysis}

Results for total polyphenolic content and antioxidant activities were reported as means \pm SD (Standard Deviation). All tests were performed in triplicate. Significant differences for multiple comparisons were made by oneway analysis of variance (ANOVA) followed by Newman Keuls's test. A significance level of $p<0.05$ was used. Data are the means of three replicates (Adandonon et al., 2009).

\section{RESULTS}

\section{Total polyphenolic content}

Analysis showed that almond beans originated from Abengourou $(41.12 \mathrm{mg}$ $\mathrm{GAE} / \mathrm{g} \pm 1.13$ ) exhibited the highest content of polyphenols followed by Adzope (27.95 $\mathrm{mg}$ GAE/g \pm 1.70 ) and Divo (22.31 mg $\mathrm{GAE} / \mathrm{g} \pm 1.14$ ). The lowest content of polyphenols was obtained with Yamoussoukro (18.27 mg GAE/g \pm 0.70 ) almond beans (Figure 1).

Concerning integument, only beans from Abengourou (9.99 mg GAE/g \pm 0.69 ) have the significantly highest content of polyphenols. Those from Adzope $(2.70 \mathrm{mg}$ GAE/g \pm 0.29), Divo (3.72 $\mathrm{mg} \mathrm{GAE} / \mathrm{g} \pm 0.40$ ) and Yamoussoukro (3.11 mg GAE/g \pm 0.3 ) expressed low polyphenol content. No statistical difference was observed among these values (Figure 1). The polyphenol content of fermented juices was significantly higher than those of fresh juices. Divo had the lowest polyphenol content of fermented juice containing (14.89 mg/g GAE/g \pm 0.57) whereas with the fresh juice, the highest polyphenol content $(14.93 \mathrm{mg} / \mathrm{g} \mathrm{GAE} / \mathrm{g} \pm$ 0.32) was obtained with Adzope (Figure 1).

Our results showed a geographic influence on the polyphenol content of different cocoa samples (Figure 2). The cocoa almonds produced in Abengourou contained the highest quantity of polyphenols compared to those obtained in Adzope, Divo and Yamoussoukro. With the integuments, highest polyphenol content was observed in cocoa originated from Abengourou, while Adzope exhibited the lowest quantity. The observations related to the fresh juice showed that cocoa originated from Adzope expressed the most important polyphenol content and the lowest was obtained in Divo (5.62 mg GAE/g \pm 0.10 ) and Abengourou (7.24 mg GAE/g \pm $0.24)$. No statistical differences were observed among the polyphenol contents of fermented juice in Abengourou (23.78 mg GAE/g \pm 0.26), Adzope (22.14 $\mathrm{mg} \mathrm{GAE} / \mathrm{g} \pm 0.70)$ and Yamoussoukro (21.81 mg GAE/g \pm 0.47 ). But these values were significantly superior to the polyphenol content obtained in Divo (14.90 $\mathrm{mg} \mathrm{GAE} / \mathrm{g} \pm 0.57$ ) (Figure 2).

Our results are in agreement with those of several authors who reported that the total polyphenol content of almond cocoa ranged from 20 to $60 \mathrm{mg} / \mathrm{g}$, sometimes up to $81.4 \mathrm{mg}$ $\mathrm{GAE} / \mathrm{g}$ and was function of assay methods, nature, origin of cocoa and processes for obtaining cocoa powders (Nazaruddin et al., 2006;Tomás-Barberán et al., 2007).

\section{Antioxidant capacity}

The antioxidant capacity of the cocoa samples was determined using the ORAC assay (Figure 3). The results revealed that almond beans from Abengourou (3881.25 $\mu \mathrm{mol} \mathrm{ET/g} \pm 58.76)$ had significantly higher antioxidant activity than those of Adzope (3039.8 $\mu \mathrm{mol} \mathrm{ET/g} \pm 15.92)$ followed by Divo $(2185.40 \mu \mathrm{mol} \quad \mathrm{ET} / \mathrm{g} \pm 12.78)$ and Yamoussoukro $(1519.81 \mu \mathrm{mol} \mathrm{ET/g} \pm 31.97)$. The values of integument ranged from Abengourou (806.62 $\mu \mathrm{mol} \mathrm{ET} / \mathrm{g} \pm 25.05)$ (highest) to Adzope $(281.06 \mu \mathrm{mol} \mathrm{ET} / \mathrm{g} \pm$ 6.78) (lowest). It is interesting to notify that there were no significant differences between antioxidant activity values of Adzope (281.06 $\mu \mathrm{mol} \mathrm{ET/g} \pm 6.78)$, Divo $(404.93 \mu \mathrm{mol} \mathrm{ET} / \mathrm{g}$ \pm 16.41 and Yamoussoukro $(298.41 \mu \mathrm{mol}$ ET/g \pm 9.41$)$. Similarly, with the juice of beans, the antioxidant activity was not statistically significant regardless of the cocoa geographical sources. However, it should be 
noted that the antioxidant activity value for fermented juice was twice higher than those of fresh juice. GU et al. (2006) using an ethanolic extraction and an ORAC assay reported values of $826 \mu \mathrm{M} \mathrm{TE} / \mathrm{g}$ for natural cocoa powder. Although this value was similar with that of the integument, it was notably lower than that found in almonds. Since polyphenols represented the major component of the cocoa bean, it is postulated that they represented the major source of antioxidant capacity in cocoa and their products (Othman et al., 2007; Jonfia-Essien et al., 2008; Slavica et al., 2011; Martin et al., 2013).

Figure 4 showed the antioxidant capacity of samples from different production areas of cocoa in Côte d'Ivoire. It can be observed that with almonds, Abengourou has antioxidant capacities significantly higher than the other regions.

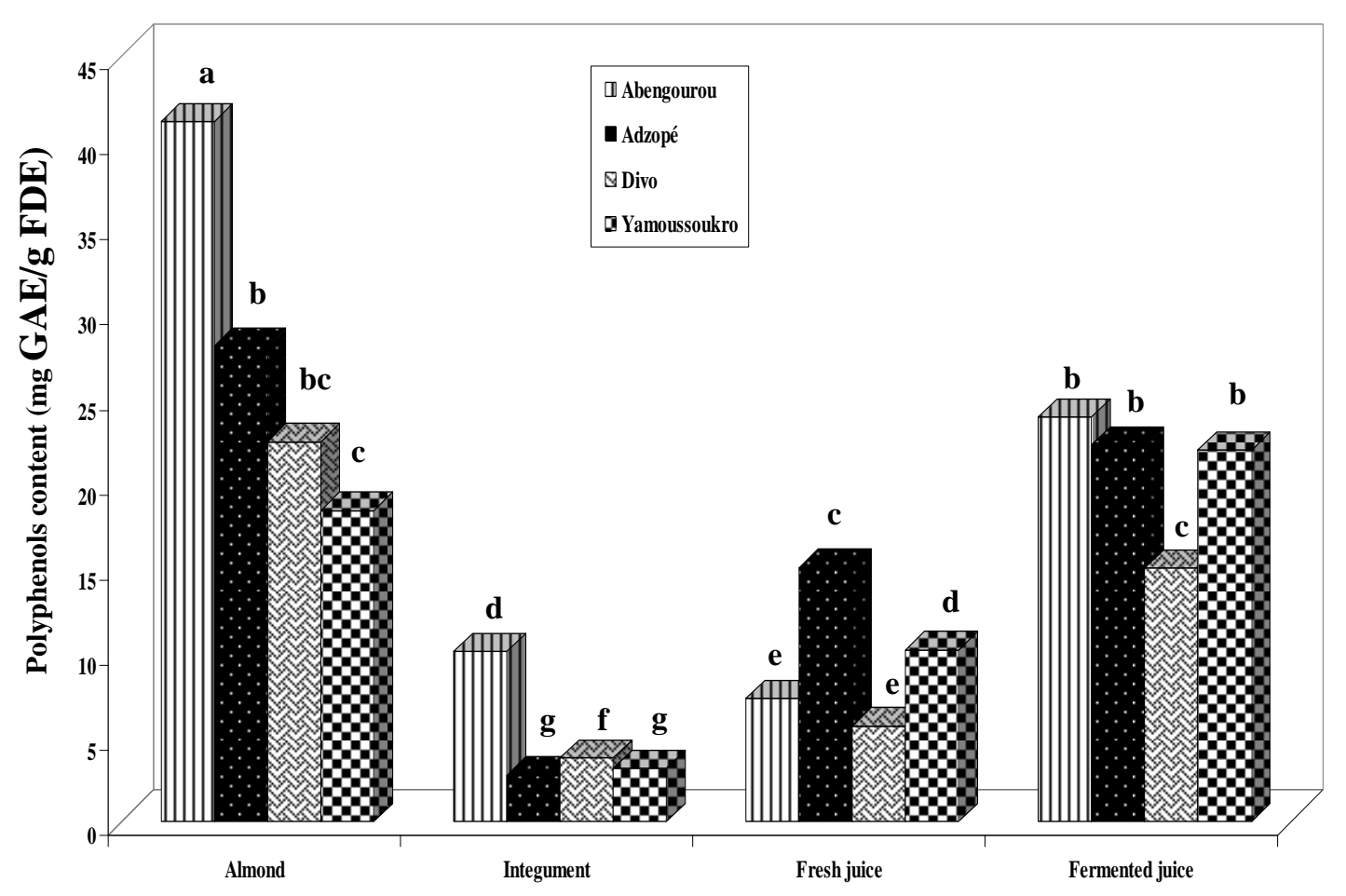

Cocoa sample

Figure 1: Polyphenols content of cocoa samplesfrom Côte d'Ivoire.

*Values followed by a different letter are significantly different, test of Newman-Keuls test $(\mathrm{P}<0.05)$.

Each value represents the mean of three replicates followed by its standard error (Adandonon et al., 2009). 


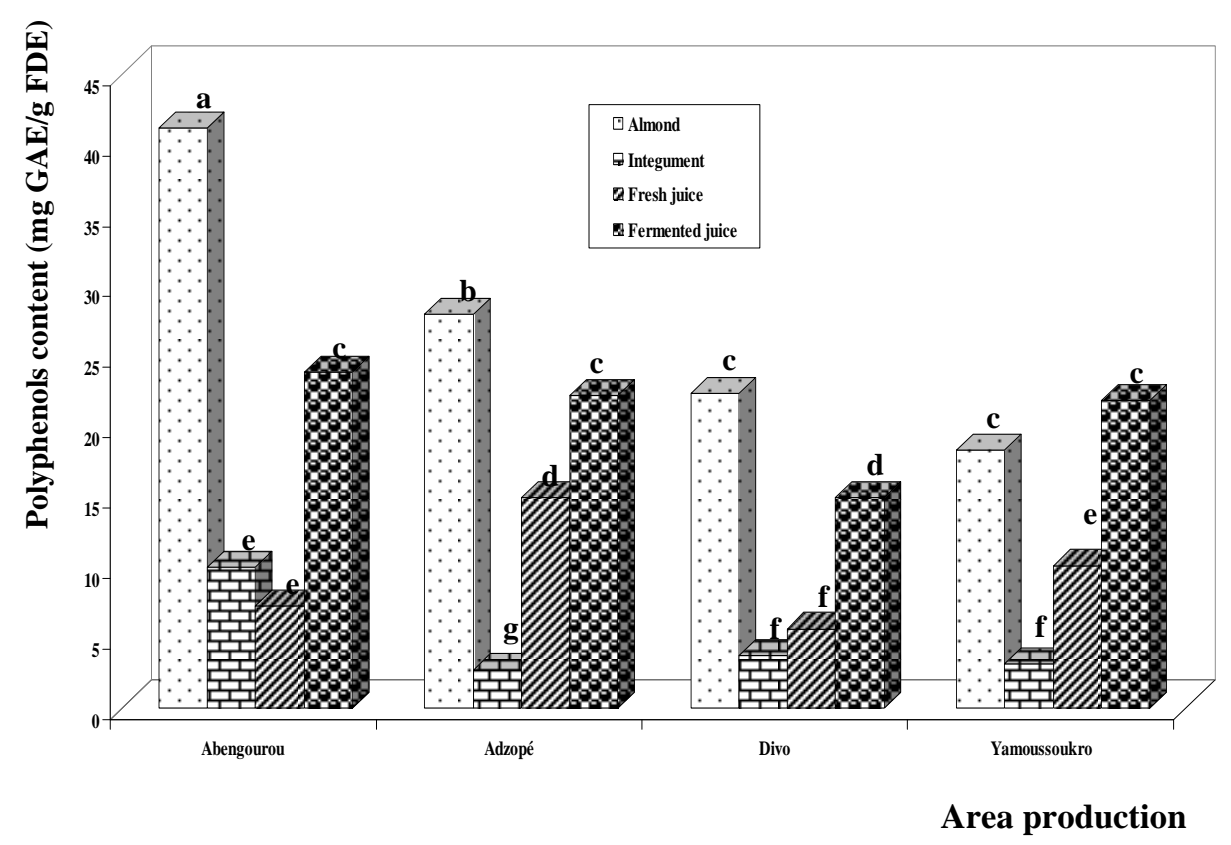

Figure 2: Polyphenols content of cocoa from production areas of cocoa in Côte d'Ivoire. *Values followed by a different letter are significantly different, test of Newman-Keuls test $(\mathrm{P}<0.05)$.

Each value represents the mean of three replicates followed by its standard error (Adandonon et al., 2009).

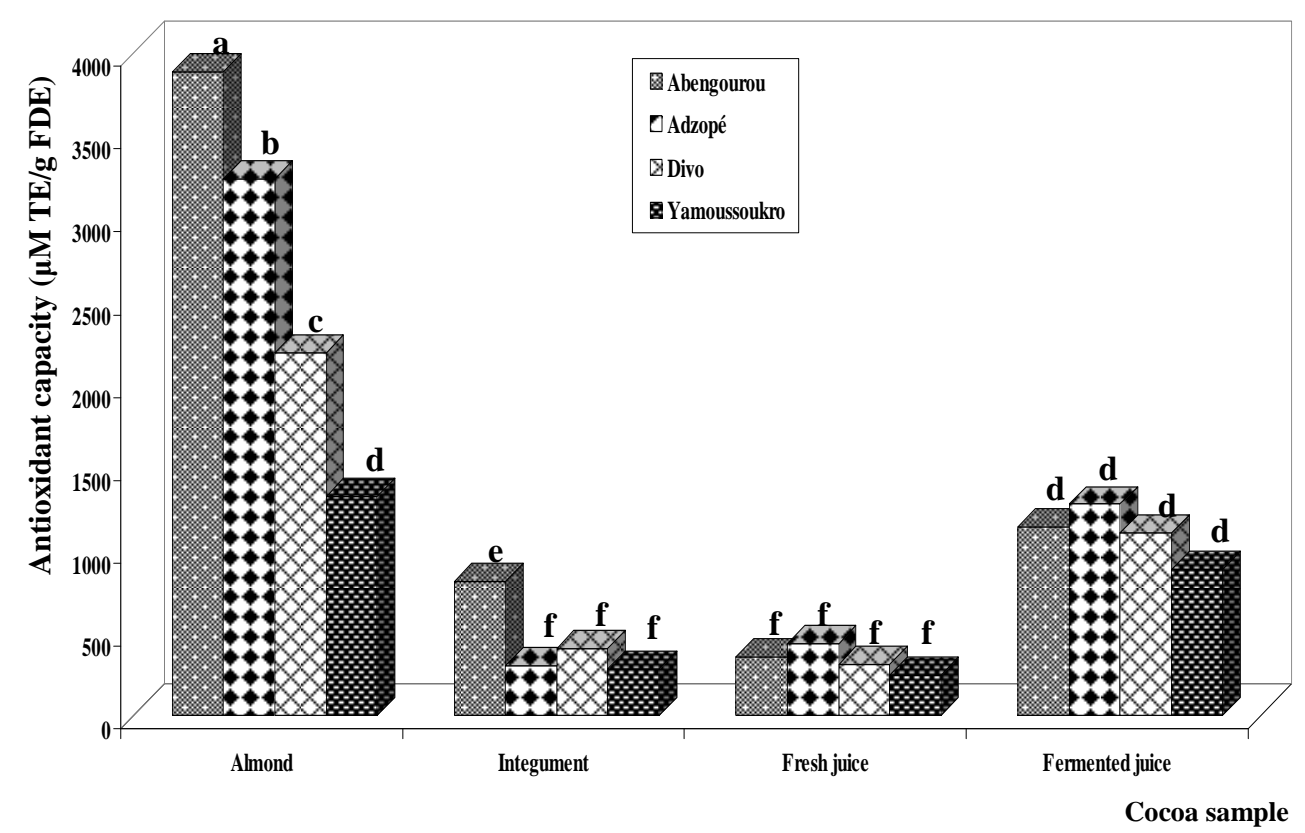

Figure 3: Antioxidant capacity of cocoa samples from Côte d'Ivoire.

*Values followed by a different letter are significantly different, test of Newman-Keuls test $(\mathrm{P}<0.05)$.

Each value represents the mean of three replicates followed by its standard error (Adandonon et al., 2009). 


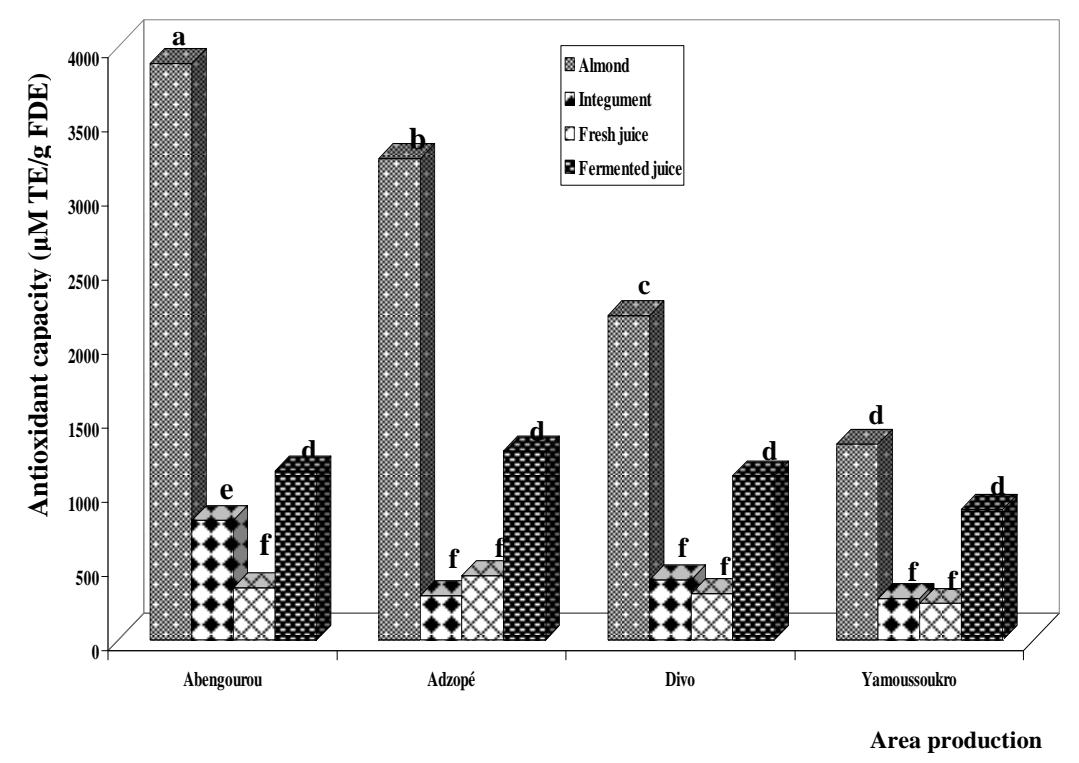

Figure 4: Antioxidant capacity of samples from production areas of cocoa in Côte d'Ivoire. *Values followed by a different letter are significantly different, test of Newman-Keuls test $(\mathrm{P}<0.05)$.

Each value represents the mean of three replicates followed by its standard error (Adandonon et al., 2009).

\section{DISCUSSION}

\section{Total polyphenolic content}

In General, total polyphenol content of fresh juice was lower than that of fermented juice. This observation could be explained by a higher sugar level which would complex fresh polyphenol juice compounds. Indeed, the fermentation process allowed the release of polyphenols in large quantities (Nazaruddin et al., 2006; Rodriguez-Campos et al., 2011).

The results revealed a sample effect on the polyphenol content in cocoa. Thus, almonds exhibited the most significant polyphenol content followed by fermented juice, fresh juice and finally integuments independently to the origin of the cocoa beans. Beans, fresh and fermented juice constituted a significant source of polyphenols that must be therefore exploited. Indeed, it would be possible to incorporate freeze-dried cocoa fermented juice in the powder of dry cocoa beans integument powder used for breakfast. Cocoa fermented juices formerly thrown by the producers could be sold to the industry and then increased the farmers' income. It is worth noting that apart from the beans, that are commonly used in chocolate factory for their richness in polyphenols, fermented juice can also be used in food and cosmetics.

As a whole, Abengourou is the production area where cocoa samples have higher total polyphenol content, except the fresh juices. This could be explained by soil conditions of Abengourou which lies to the East of Côte d'Ivoire. Indeed, Abengourou has strongly desaturated ferralitic soils, Adzope the silty-clay soils, Divo the lateritic soils and Yamoussoukro reddish soil more or less gravelly. With regard to the climate, only Yamoussoukro is on the border of the forest and savanna and located in the humid forest zone with good annual rainfall. There would be an influence of geographical sources on the biosynthesis of cocoa polyphenols (Carrillo et 
al., 2013). The new variety of cocoa currently cultivated in Côte d'Ivoire, Abengourou seems to be the best production area in terms of cocoa nutritional quality. Knowing the phenolic pool, the bulk cocoa was no longer sold on the international market but it was sold selectively according to the needs of industry. Thus, we can therefore have a traceable cocoa coming from Côte d'Ivoire. The results of this study could be useful for the cocoa industry to produce new food products from cocoa juice.

\section{Antioxidant capacity}

Abengourou seems to be the best geographical area of producing cocoa in terms of antioxidant capacity. For fresh and fermented juice, antioxidant capacities were identical whatever the geographic source of cocoa. But, it should be noted that the antioxidant activity of fermented juice was the double of that of the fresh juice. Except Abengourou, antioxidant activity is similar and lower in the other area production of cocoa for the integument. We notice clearly that with antioxidant capacity, only almond beans can discriminate the best areas of cocoa production. So, there was an influence of geographical source of cocoa antioxidant capacity on the analyzed samples (Carrillo et al., 2013). This was similar to the work of Othman et al. (2007) who monitored polyphenols and antioxidant capacity in beans from a range of geographical sources and demonstrated that there was a significant effect of production area on these parameters and that a good correlation could be made between total polyphenols and antioxidant capacity. In the same way, Gu et al. (2006) have demonstrated a good correlation between total polyphenols and antioxidant capacity in cocoa beans and their products.

It is interesting to note that in the present study, while polyphenol content has apparently varied with geographical sources of cocoa, antioxidant capacity was not affected, except Abengourou. However, when we considered almonds, there was a strong correlation between the polyphenol content and antioxidant activity. Indeed antioxidant variability depended on the production area of cocoa. This would mean that the quality of the synthesized polyphenol cocoa beans depended on the geographical source. Also, these results implied that all polyphenols presented in cocoa did not have antioxidant activity. The absence of correlation between polyphenol content and antioxidant capacity observed in other production area of cocoa might suggest the presence of other important antioxidants in the cocoa bean.

\section{Conclusion}

The present results seem to show a difference between cocoa coming from Abengourou and those of other production areas in terms of nutritional quality. For polyphenols, Adzope ranks second followed by Divo and finally Yamoussoukro. For antioxidant capacity, Abengourou stands alone and no significant difference was observed in the other production areas. On the basis of this study, the introduction of cocoa in Abengourou for commercial trade would have a positive impact on the availability of polyphenols having antioxidant activity in nutrients for consumers.

Further studies would be necessary to explain on the one hand, the complexity of the relative concentration of polyphenols and antioxidants in cocoa, and on the second hand, the relationship between soil quality (mineral contents), polyphenols and antioxidant content in cocoa with soil analysis.

\section{ACKNOWLEDGEMENTS}

This study was supported by GESVAB (Groupe d'Etudes des Substances Végétales à Activités Biologiques) from University of Bordeaux 2. The authors are grateful to CNRA and ANADER for supplying cocoa pods. 


\section{REFERENCES}

Abbe MMJ, Amin I. 2008. Polyphenols in Cocoa and Cocoa Products: Is There a Link between Antioxidant Properties and Health? Molecules, 13: 2190-2219.

Adandonon A, Vayssières J-F, Sinzogan A, Van Mele P. 2009. Density of pheromone sources of the weaver and Oecophylla longinoda affects oviposition behaviour and damage by mango fruit flies (Diptera: Tephritidae). Int. J. Pest. Manage, 55: 285-292.

Carrillo LC, Londono-Londono J, Gil A. 2013. Comparison of polyphenol, methylxanthines and antioxidant activity in Theobroma cacao beans from different cocoa-growing areas in Colombia. Food Research International, http://dx.doi.org/ 10.1016/j.foodres.2013.06.019.

Cho ES, Lee KW, Lee HJ. 2008. Cocoa procyanidins protect PC12 cells from hydrogen-peroxide-induced apoptosis by inhibiting activation of p38 MAPK and JNK. Mutation Research, 640: 123-130.

Davalos A, Cordovés CG, Bartolomé B. 2004. Extending Applicability of the Oxygen Radical Absorbance Capacity (ORAC-Fluorescein) Assay. Journal of Agricultural and Food Chemistry, 52: 4854.

Engler MB, Engler MM, Chen CY, Malloy MJ, Browne A, Chiu EY, Kwak HK, Milbury P, Paul SM, Blumberg J, Mietus-Snyder ML. 2004. Flavonoid-rich dark chocolate improves endothelial function and increases plasma epicatechin concentrations in healthy adults. Journal of the American College of Nutrition, 23: 197-204.

Fernández-Murga L, Tarín JJ, García-Perez MA, Cano A. 2011. The impact of chocolate on cardiovascular health. Maturitas, 69: 312-321.

Gillespie KM, Chae JM, Ainsworth EA. 2007. Rapid measurement of total antioxidant capacity in plants. Nature Protocols, 2: 867-870.

Gu L, House SE, Wu X, Ou B, Prior RL. 2006. Procyanidin and catechin contents and antioxidant capacity of cocoa and chocholate products. Journal of Agricultural and Food Chemistry, 54: 4057-4061.

Jonfia-Essien WA, West G, Alderson PG, Tucker G. 2008. Phenolic content and antioxidant capacity of hybrid variety cocoa beans. Food Chemistry, 108: 11551159.

Hii CL, Law CL, Suzannah S, Misnawi, Cloke M. 2009. Polyphenols in cocoa (Theobroma cacao L.). Journal of Food and Agro-Industry, 2(04): 702-722.

Khan MTH, Ather A. 2007. Potentials of phenolic molecules of natural origin and their derivatives as anti-HIV agents. Biotechnology Annual Review, 13: 223264.

Kanadaswami C, Lee LT, Lee PP, Hwang JJ, Ke FC, Huang YT,Lee MT. 2005. The antitumor activities of flavonoids. In Vivo, 19: 895-909.

Keen CL, Holt RR, Oteiza PI, Fraga CG, Schmitz HH. 2005. Cocoa antioxidants and cardiovascular health. American Journal of Clinical Nutrition, 81: 298S303S.

Martin MA, Goya L, Ramos S. 2013. Potential for preventive effects of cocoa and cocoa polyphenols in cancer. Food and Chemical Toxicology, 56: 336-351.

Martín MA, Serrano ABG, Ramos S, Pulido MI, Bravo L, Goya L. 2010. Cocoa flavonoids up-regulate antioxidant enzyme activity via the ERK1/2 pathway to protect against oxidative stress-induced apoptosis in HepG2 cells. Journal of Nutritional Biochemistry, 21: 196-205.

Naczk M, Shahidi F. 2004. Extraction and analysis of phenolics in food. Journal of Chromatography A, 1054: 95-111. 
Nazaruddin R, Seng LK, Hassan O, Said M. 2006. Effect of pulp preconditioning on the content of polyphenols in cocoa beans (Theobroma Cacao) during fermentation. Industrial Crops and Products, 24: 8794.

Othman A, Abbe M, Kong KW, Amin I, Nawalyah AG, Ilham A. 2010. Epicatechin content and antioxidant capacity of cocoa beans from four different countries. African Journal of Biotechnology, 9(7): 1052-1059.

Othman A, Ismail A, Ghani NA, Adenan I. 2007. Antioxidant capacity and phenolics content of cocoa beans. Food Chemistry, 100: $1523-1530$.

Rodriguez-Campos J, Escalona-Buendía HB, Orozco-Avila I, Lugo-Cervantes E, Jaramillo-Flores ME. 2011. Dynamics of volatile and non-volatile compounds in cocoa (Theobroma cacao L.) during fermentation and drying processes using principal components analysis. Food Research International, 44: 250-258.
Slavica MJ, Ivana RR, Ksenija M, Durdica IS, Karmela D. 2011. Changes of phenolic compounds and antioxidant capacity in cocoa beans processing. International Journal of Food Science and Technology, 46(9): 1793-1800.

Tomas-Barberan FA, Cienfuegos-Jovellanos E, Marin A, Muguerza B, Gil-Izquierdo A, Cerda B, Zafrilla P, Morillas J, Mulero J, Ibarra A, Pasamar MA, Ramon D, Espin JC. 2007. A new process to develop a cocoa powder with higher flavonoid monomer content and enhanced bioavailability in healthy humans. $J$. Agric. Food Chem., 55: 3926-3935.

Valko M, Leibfritz D, Moncola J, Cronin MTD, Mazura M, Telser J. 2007. Free radicals and antioxidants in normal physiological functions and human disease. International Journal of Biochemistry and Cell Biology, 39: 4484. www.cnra.ci 